\title{
肝硬変を合併した血液透析患者におけるアセテート透析の影響
}

\author{
山田雅仁菱田明米村克彦米山孝 \\ 本田西男 \\ 浜松医科大学第 1 内科
}

(平成 1 年 8 月 7 日受付，同 2 年 6 月 21 日受理)

key words : 肝硬変, 血液透析, アセテート代謝, 慢性腎不全, 酸塩基平衡

〈要旨〉

肝硬変を合併した血液透析患者 3 名にアセテート透析を行い, 透析前後での血漿アセテート濃度の変化, 酸塩基平 衡への影響を肝機能の正常な血液透析患者 3 名と比較検討した.

アセテート透析により上昇した血漿アセテート濃度の最高值は, 肝硬変患者で $2.1 \sim 2.6 \mathrm{mEq} / l$ であり, 肝機能正 常者での值 $(2.6 \sim 3.2 \mathrm{mEq} / l)$ に比し高值とならなかった。 また, 肝硬変患者での血液透析前後の動脈血中 $\mathrm{pH}$ およ び $\mathrm{HCO}_{3}^{-}$濃度は, 平均值でそれぞれ 7.38 $\rightarrow 7.45,18.7 \rightarrow 21.6 \mathrm{mEq} / l$ と上昇しており, これは肝機能正常者での值(光 れぞれ 7.37 $\rightarrow 7.41,19.0 \rightarrow 20.4 \mathrm{mEq} / l)$ とほぼ同程度の変化であった。 したがって, 肝硬変を合併した血液透析患者 でもアセテート代謝の面からはアセテート透析を行うことに問題は少ないと考えられた。

\section{The effects of acetate dialysate on plasma acetate concentration and blood acid-base condition in chronic hemodialysis patients complicated with liver cirrhosis}

\author{
Masahito Yamada, Akira Hishida, Katsuhiko Yonemura, Takashi Yoneyama, Nishio Honda \\ First Department of Internal Medicine, Hamamatsu University School of Medicine
}

This study was performed to evaluate whether the existence of liver dysfunction in chronic uremic patients affects the metabolism of acetate which is loaded during dialysis with acetate dialysate.

Plasma acetate concentration, blood $\mathrm{pH}$ and $\mathrm{HCO}_{3}{ }^{-}$concentration were evaluated at $0,1,3$ and $5 \mathrm{hrs}$ after the start of dialysis in 3 chronic hemodialysis patients complicated with liver cirrhosis and 3 chronic hemodialysis patients without liver dysfunction.

The maximal plasma acetate concentrations were $2.1,2.5$ and $2.6 \mathrm{mEq} / l$ in cirrhotic patients and $2.6,3.0$ and 3.2 in hemodialysis patients without liver dysfunction. The blood $\mathrm{pH}$ and $\mathrm{HCO}_{3}{ }^{-}$concentration in cirrhotic patients were increased from 7.38 to 7.45 and from 18.7 to $21.6 \mathrm{mEq} / \mathrm{l}$ respectively by acetate dialysis. In patients without liver dysfunction, blood $\mathrm{pH}$ and $\mathrm{HCO}_{3}{ }^{-}$concentration increased from 7.37 to 7.41 and from 19.0 to $20.4 \mathrm{mEq} / l$ respectively.

These results suggest that the existence of liver dysfunction in chronic hemodialysis patients does not affect the changes induced by acetate dialysis in plasma acetate concentration, the blood $\mathrm{pH}$ and $\mathrm{HCO}_{3}{ }^{-}$concentration.

\section{緒言・目的}

血液透析のアルカリ剂として用いられるアセテート は，主として筋肉で代謝されて重曹になるが ${ }^{1,2)}$, 一部は

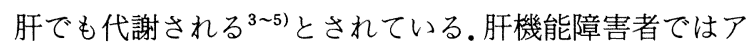
セテートの代謝が損なわれている可能性があり, アセ テート透析のように短時間に大量のアセテートが体内に

山田 雅仁 浜松医科大学第 1 内科

于 431-31 浜松市半田町 3600 (0534-35-2111)

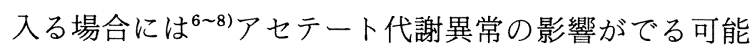
性がある. 今回この点を検討するため, 肝硬変を合併し た血液透析患者でアセテート透析を行い, 血中アセテー ト濃度および酸塩基平衡への影響を検討した。 方法

肝硬変を合併した血液透析患者 3 名（肝硬変群）と肝 機能の正常な血液透析患者 3 名（肝機能正常群）を用い た. 肝硬変の診断は, 病歴, 臨床経過, 理学的所見, 血 
表 1 肝硬変患者の検查所見

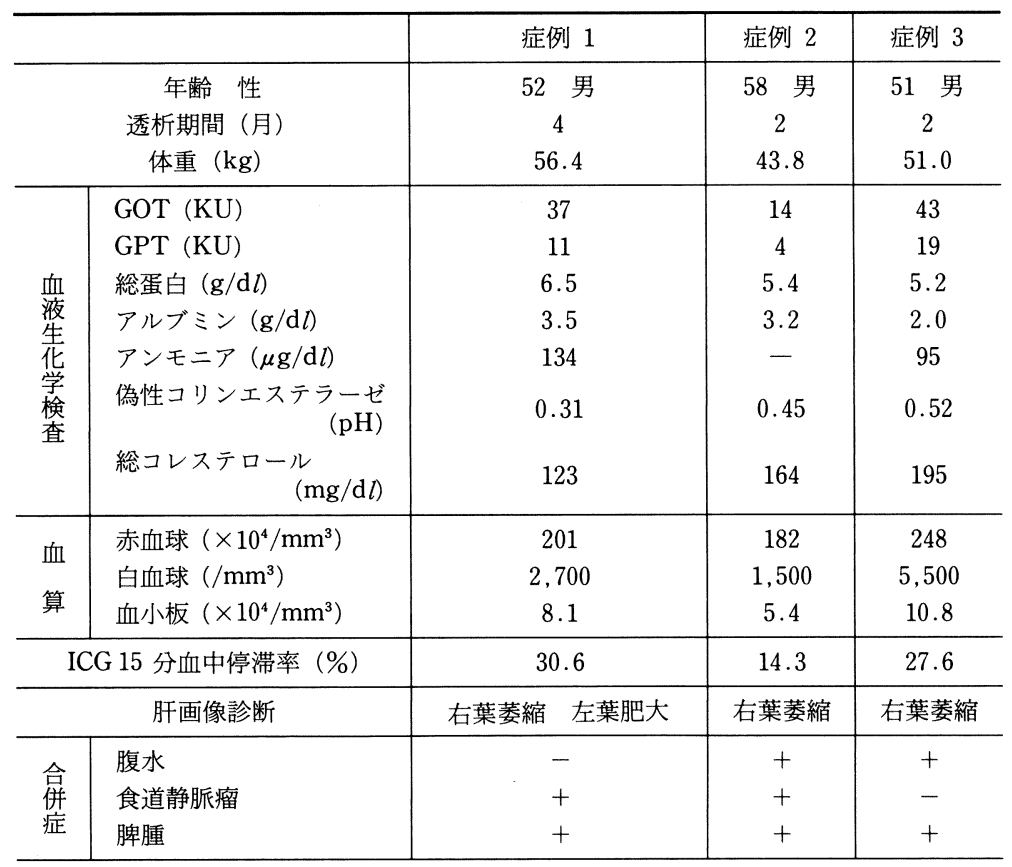

表 2 透析条件

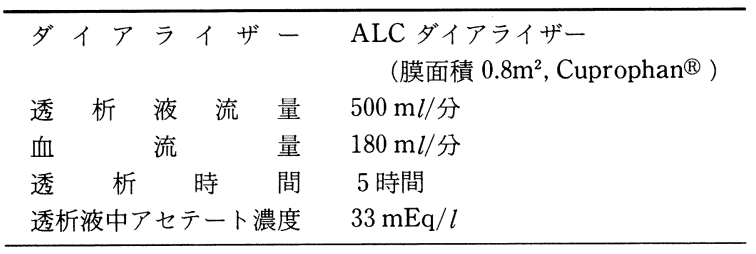

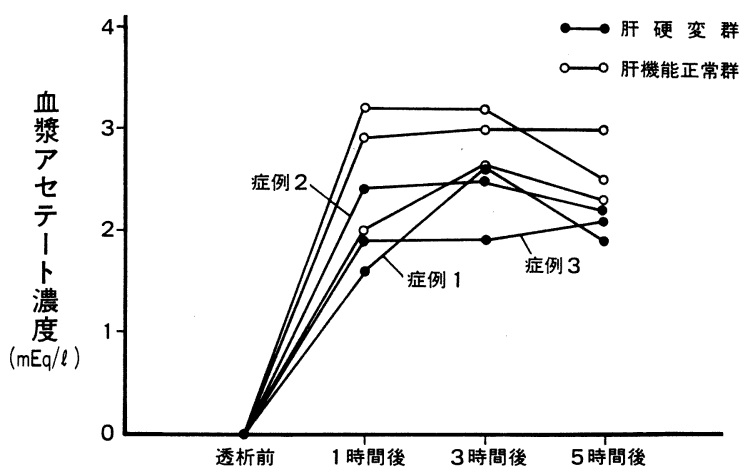

図 1 血漿アセテート濃度の変化

液生化学的所見, 消化管内視鏡および画像所見（肝右葉 萎縮左葉腫大, 脾腫, 肝シンチグラムでの椎骨や脾への RI の取り込み) から臨床的に行った. 肝硬変患者の年齢, 性, 透析期間, 体重および検查所見は表 1 に示す通りで

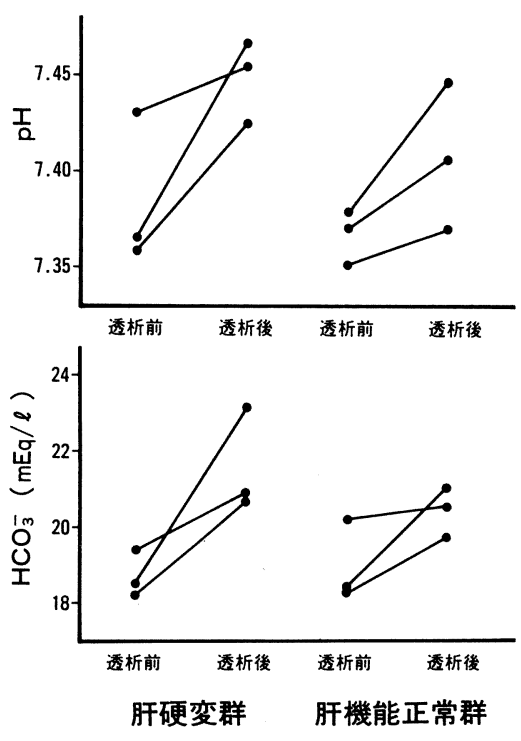

図 2 アセテート透析による動脈血 $\mathrm{pH}, \mathrm{HCO}_{3}^{-}$ の変化

ある. 対照に用いた肝機能正常患者は, 女性 2 名 (49 歳, 51 歳）と男性 1 名（67 歳）であり，体重および透析期間 はそれぞれ 42.1〜 46.4 kg, 4〜58 か月であった. 透析条 件は全例表 2 に示す同一の条件で行った. また, 今回の 検討はいずれも前回透析の 2 日後の透析日に行った. 両 群の患者につき, 透析直前, 透析開始 $1,3,5$ 時間後 
に内シャントまたは透析回路内のダイアライザー前部よ り採血した，血漿アセテート濃度は酵素法によって測定 した ${ }^{9)}$. また, 透析直前, 直後に動脈血採血を行い, 動脈 血 $\mathrm{pH}$ と $\mathrm{HCO}_{3}^{-}$濃度を測定した。

\section{結果}

透析前後の血獎アセテート濃度の変化を図 1 に示す. 肝硬変群, 肝機能正常群とも透析開始 1 時間後までに血 漿アセテート濃度は上昇し, 以後はほほ一定であった。 透析開始後のいずれの時点でも両群の間に明らかな差を 認めなかった。 また, 各患者での血漿アセテート濃度の 最高值をみてみると, 肝硬変群で $2.6,2.5,2.1 \mathrm{mEq} / l$ (平 均 $2.4 \mathrm{mEq} / l$ ), 肝機能正常群で $3.2,3.0,2.6 \mathrm{mEq} / l$ (平 均 $2.9 \mathrm{mEq} / l$ ) であり, 肝硬変群で高い傾向はみられな かった. 透析前後の酸塩基平衝の状態を図 2 に示すが, 透析後の動脈血 $\mathrm{pH}$ および $\mathrm{HCO}_{3}^{-}$濃度はともに両群で 同程度上昇した。

\section{考察}

アセテート透析時, 体内に入ったアセテートは, 主と して酸化により代謝されるとされているが，アセテート 透析によって体内に入るアセテートの量は, 体内でのア セテート酸化の最大能（約 $4.5 \mathrm{mmol} /$ 時 $/ \mathrm{kg}$ 体重）に近 いとされており ${ }^{6 \sim 9)}$,アセテート代謝が損なわれる状態で は体内にアセテートが蓄積する可能性がある。こうした 場合，気分不快や血圧低下などをきたしたり，アセテー トからの $\mathrm{HCO}_{3}^{-}$生成不全をきたしアシドーシスの是正 が障害される可能性がある ${ }^{1,11,12)}$.アセテート代謝の主要 部位は筋肉であるとされているが ${ }^{1,2)}$, アセテートの代謝 酵素と考えられている acetyl-CoA synthetase がラット の肝で比較的高い活性をもつとの報告 ${ }^{3}$ があり，また，肝 切除でアセテート利用率の減少をみたとする報告)もあ り，アセテート代謝に肝が一部関与することが示唆され ている.したがって, 肝機能障害を合併する透析患者で はアセテート代謝が損なわれ, 前述のような問題を引き 起こす可能性がある，すでに Mansell ら ${ }^{13)}$ は，急性肝障 害を伴う腎不全患者にアセテート透析を行い, 血中アセ テート值の異常高值を認めなかったと報告しているが, 肝硬変患者でのアセテート透析の影響について検討した 報告はない. 今回我々は, 肝硬変を合併する透析患者 3 名についてアセテート透析中のアセテート濃度の上昇, 血液酸塩基平衡の是正の程度を検討した。その結果, 肝 機能正常患者に比し著変はなかった，すなわち，肝硬変 患者は 3 例とも血墏アセテート濃度の異常な上昇を認め ず，また，酸塩基平衡障害の是正も行われていた。

今回検討した肝機能障害者では, 血清アルブミン濃度 は平均值で $2.9 \mathrm{~g} / \mathrm{d} l$ であり，蛋白質合成能の低下は必ず しも重篤とはいえず, 重篤な肝機能障害を持った患者で
のアセテート透析の安全性や有用性については今後の検 討が必要である．また，今回の検討に用いたダイアライ ザーは, 膜面積が $0.8 \mathrm{~m}^{2}$ と比較的小さいものであり,よ り膜面積の大きいダイアライザーを用いた場合の安全性 についても今後の検討が必要である ${ }^{14)}$.

\section{結論}

肝硬変を合併する血液透析患者 3 名に户セテート透析 を行ったが, 肝機能正常者 3 名と比べて血漿アセテート 濃度の異常な上昇やアシドーシス是正障害は認められな かった.

\section{文献}

1) Vinay $P$, Prud homme $M$, Vinet $B$, Cournoyer $G$, Degoulet P, Leville M, Gougoux A, St-Louis G, Lapierre L, Piette Y : Acetate metabolism and bicarbonate generation during hemodialysis : 10 years of observation. Kidney Int $31: 1194-1204$, 1987

2) Jorfeldt L, Juhlin-Danfelt $A$ : Influence of ethanol on splanchnic and skeletal muscle metabolism in man. Metabolism 27 : 97-106, 1978

3) Knowles SE, Jarrett IG, Filsell OH, Ballard FJ : Production and utilization of acetate in mammals. Biochem J 142 : 401-411, 1974

4) Harper PV, Neal WB, Hlavacek GR : Acetate utilization in the dog. Metabolism $2: 62-68,1953$

5) Ballard FJ : Supply and utilization of acetate in mammals. Am J Clin Nutr 25 : 773-779, 1972

6) Kveim M, Nesbakken R: Utilization of exogenous acetate during hemodialysis. Trans Am Soc Artif Intern Organs 21 : 138-143, 1975

7) Skutches CL, Sigler MH, Teehan BP, Cooper JH, Reichard GA : Contribution of dialysate acetate to energy metabolism: Metabolic implications. Kidney Int $23: 57-63,1983$

8) Gonzalez FM, Pearson JE, Garbus SB, Holbert RD : On the effects of acetate during hemodialysis. Trans Am Soc Artif Intern Organs $20: 169-174,1974$

9）橋本一夫, 山本修平, 関野 宏, 堀端建吾: 酵素法 （F-キット，ベーリンガー・マンハイム）による血 中酶酸の測定および東芝 TBA-360による自動化の 検討. 臨床検查機器・試薬 $3: 123-128,1980$

10) Lundquist $F:$ Production and utilization of free acetate in man. Nature $193: 579-580,1962$

11) Novello A, Kelsh RC, Esterling RE : Acetate in- 
tolerance during hemodialysis. Clin Nephrol $5: 29$ $-32,1976$

12) Molnar JI, Scott JB, Frohlich ED, Haddy FJ : Local effects of various anions and $\mathrm{H}^{+}$on $\mathrm{dog}$ limb and coronary vascular resistances. Am J Physiol 203 : 125-132, 1962

13) Mansell MA, Nunan TO, Laker MF, Boon NA,
Wing $\mathrm{AJ}$ : Incidence and significance of rising blood acetate levels during hemodialysis. Clin Nephrol 12 : 22-25, 1979

14) Lewis EJ, Tolchin N, Roberts JL : Estimation of the metabolic conversion of acetate to bicarbonate during hemodialysis. Kidney Int 18(Suppl 10) : 51-55, 1980 